\title{
The peculiarities of pathogenesis of NSAID-induced gastrointestinal injuries and current prevention strategies
}

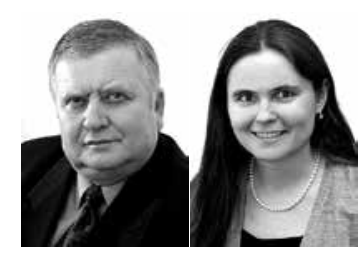

\section{Specyfika patogenezy uszkodzeń błony śluzowej żoładka i jelit wywołanych przez niesteroidowe leki przeciwzapalne i wspótczesne strategie ich profilaktyki}

\author{
Anatol Święcicki, Antonina Antonienko \\ Department of Internal Medicine No 3, Bogomolets National Medical University, Kyiv, Ukraine \\ Katedra Medycyny Wewnętrznej nr 3, Narodowy Uniwersytet Medyczny im. O.O. Bohomolca, Kijów, Ukraina
}

Key words: NSAID gastropathy, cyclooxygenase, lipoxins, prostaglandins, NSAID enteropathy.

Słowa kluczowe: gastropatia indukowana przez NLPZ, cyklooksygenaza, lipoksyny, prostaglandyny,

enteropatia indukowana przez NLPZ.

\section{Sum mary}

Nonsteroidal anti-inflammatory drugs (NSAIDs) are among the most widely used medications. However, NSAID intake is accompanied by an increased risk of gastroduodenal side effects. These adverse events are largely attributed to the ability of these drugs to suppress prostaglandin synthesis, penetrate the mucosal layer in the acid media of the stomach and damage epithelial cells. However, it is becoming clear that such mediators as prostaglandins, NO and lipoxins can protect the stomach from injury. This injury can largely be prevented through suppression of gastric acid secretion (mainly with proton pump inhibitors). In contrast, the pathogenesis of intestinal injury induced by NSAIDs is less well understood. There is no evidence that suppression of gastric acid secretion will reduce the incidence or severity of NSAID enteropathy. In this review the results of recent studies are described, which will help to clarify some mechanisms of development of NSAID gastropathies and NSAID enteropathies and to improve the treatment of these patients.

Nonsteroidal anti-inflammatory drugs (NSAIDs), which have anti-inflammatory, antipyretic and analgesic effects, are among the most widely used medications worldwide. At the same time NSAID use is associated with a wide range of side effects, the most usual being those involving the gastrointestinal (GI) tract.

\section{Streszczenie}

Niesteroidowe leki przeciwzapalne (NLPZ) są jednymi z najpowszechniej stosowanych leków. Spożycie NLPZ jest jednak związane ze zwiększonym ryzykiem wystąpienia działań niepożądanych w przewodzie pokarmowym. Te działania niepożądane są spowodowane zdolnością NLPZ do hamowania syntezy prostaglandyn, ich przenikania do błony śluzowej żołądka i powodowania uszkodzeń komórek nabłonkowych. Wiadomo, że takie mediatory, jak prostaglandyny, tlenek azotu i lipoksyny, mają zdolność ochrony przed uszkodzeniami błony śluzowej żołądka. Uszkodzeniom błony śluzowej można zapobiegać poprzez hamowanie wydzielania kwasu żołądkowego (przede wszystkim za pomocą inhibitorów pompy protonowej). W przeciwieństwie do uszkodzeń błony śluzowej żołądka, uszkodzenia błony śluzowej jelita cienkiego pod wpływem NLPZ są słabiej poznane. Problem ewentualnego uzależnienia enteropatii indukowanej przez NLPZ od poziomu wydzielania kwasu żołądkowego nie jest dostatecznie dobrze poznany. W artykule przedstawiono wyniki najnowszych badań, dzięki którym można wyjaśnić niektóre mechanizmy gastropatii i enteropatii indukowanych przez NLPZ z myślą o poprawie leczenia pacjentów.

Niesteroidowe leki przeciwzapalne (NLPZ) należą do najczęściej stosowanych leków na świecie. Charakteryzują się działaniem przeciwzapalnym, przeciwgorączkowym i przeciwbólowym. Stosowanie leków z grupy NLPZ wiąże się jednak z licznymi działaniami niepożądanymi, z których większość dotyczy układu pokarmowego.

Address for correspondence:

Prof. Anatol Święcicki, Department of Internal Medicine No 3, Bogomolets National Medical University, Kyiv, Ukraine, e-mail: sasnmu@mail.ru Submitted: 27.04.2014 r. 
Mechanisms of gastric and duodenal lesions are related to blockage of prostaglandin synthesis, membrane permeabilization and production of additional proinflammatory mediators. By inhibiting cyclooxygenases (COX) NSAIDs block the formation not only of proinflammatory but also of gastroprotective prostaglandins. At the same time NSAIDs are characterized by a direct cytotoxic effect on gastric mucosal cells, causing lesions and injury. According to several studies, direct cytotoxicity is independent of the inhibition of COX activity [1]. NSAIDs cause membrane permeabilization leading to disruption of the epithelial barrier with further necrosis and apoptosis in gastric mucosal cells (Fig. 1).

New strategies for the treatment of inflammatory diseases associated with decreased risk of the development of NSAID gastropathies are hydrogen sulfide releasing NSAIDs, phosphatidylcholine-associated NSAIDs, NO-NSAIDs and inhibitors of 5-lipoxygenase.

In recent years, the physiological roles of hydrogen sulfide $\left(\mathrm{H}_{2} \mathrm{~S}\right)$ have been recognized, and there is emerging evidence that this endogenous gaseous substance can modulate inflammatory processes. $\mathrm{H}_{2} \mathrm{~S}$-releasing derivatives of NSAIDs, including selective COX-2 inhibitors, stimulate adherence of leukocytes to the vascular endothelium in the mesenteric circulation. $\mathrm{H}_{2} \mathrm{~S}$ donors have been shown to reduce edema formation and leukocyte adherence to the vascular endothelium,
Mechanizm powstawania zmian w obrębie żołądka i dwunastnicy obejmuje proces blokowania syntezy prostaglandyn, a także zwiększenie przepuszczalności (permeabilizację) błony komórkowej oraz wytwarzanie dodatkowych mediatorów prozapalnych. Poprzez hamowanie aktywności cyklooksygenaz (COX) NLPZ blokują powstawanie nie tylko prostaglandyn prozapalnych, lecz także gastroprotekcyjnych. Jednocześnie NLPZ wywołują bezpośrednie działanie cytotoksyczne na komórki błony śluzowej żołądka, powodując zmiany i uszkodzenia. Zgodnie z wynikami uzyskanymi w kilku badaniach bezpośredni efekt cytotoksyczny jest niezależny od hamowania aktywności COX [1]. Niesteroidowe leki przeciwzapalne powodują permeabilizację błony komórkowej, co skutkuje zaburzeniem funkcjonowania bariery naskórkowej, stopniowo prowadząc do martwicy i apoptozy w obrębie komórek błony komórkowej żołądka (ryc. 1).

Wśród nowych strategii leczenia chorób zapalnych, które pozwalają zmniejszyć ryzyko gastropatii indukowanych przez NLPZ, należy wymienić NLPZ uwalniające siarkowodór $\left(\mathrm{H}_{2} \mathrm{~S}\right)$, NLPZ w postaci kompleksów z fosfatydylocholiną, NLPZ uwalniające NO oraz inhibitory 5-lipooksygenazy.

W ostatnim czasie udało się lepiej poznać funkcje fizjologiczne $\mathrm{H}_{2} \mathrm{~S}$ i pojawia się coraz więcej dowodów potwierdzających, że ten wytwarzany endogennie gaz może modulować procesy zapalne. Pochodne NLPZ uwalniające $\mathrm{H}_{2} \mathrm{~S}$, w tym selektywne inhibitory COX-2, po-

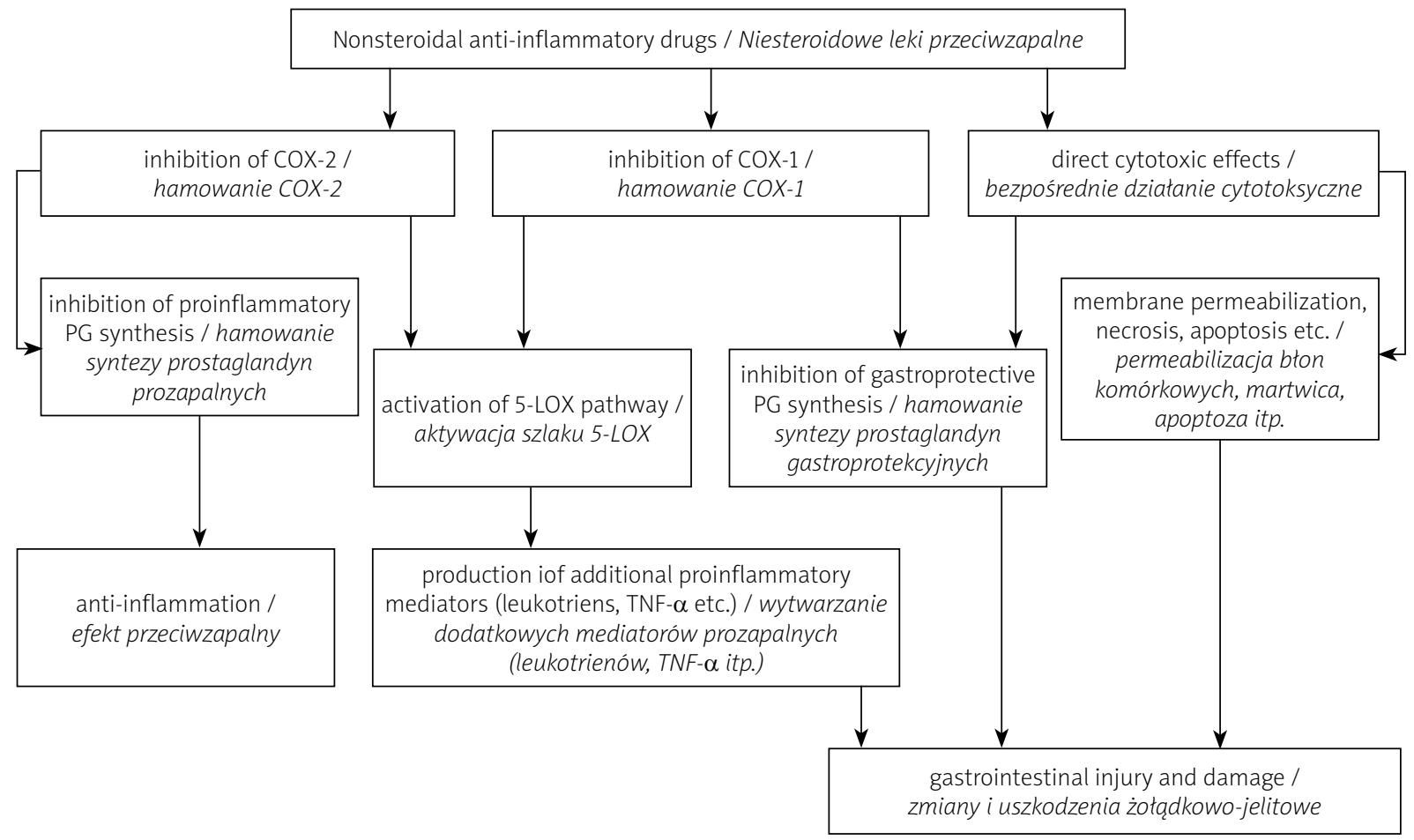

Fig. 1. Mechanisms of NSAID-induced gastrointestinal injury [1].

Ryc. 1. Mechanizm powstawania uszkodzeń błony śluzowej żołądka i jelit wywoływanych przez NLPZ [1]. 
to inhibit pro-inflammatory cytokine synthesis and to increase the resistance of the gastric mucosa to injury and accelerate repair. In rats $\mathrm{H}_{2} \mathrm{~S}$ donors were shown to suppress leukocyte adherence to the vascular endothelium induced by superfusion of mesenteric venules with a pro-inflammatory peptide, formyl-methionyl-leucyl-phenylalanine, and this has been shown to contribute significantly to the pathogenesis of NSAID-induced gastric damage [2]. Taken together, these observations and others suggest that anti-inflammatory drugs that are modified to release $\mathrm{H}_{2} \mathrm{~S}$ will exhibit improved efficacy and reduced toxicity.

Lipoxin $A_{4}\left(L X A_{4}\right)$ and lipoxin $B_{4}\left(L X B_{4}\right)$ were first identified as 5- and 15-lipoxygenase interaction products of activated leukocytes. But later lipoxins were found also in tissue cells of patients with various immuno-inflammatory states such as rheumatoid arthritis, asthma, pneumonia, etc. NSAIDs are considerably involved in lipoxin biosynthesis because they can acetylate a key serine residue in both COX-1 and COX-2, leading to inhibition of the production of prostanoids from arachidonic acid. While COX-1 activity appears to be completely inhibited, however, COX-2 can still convert arachidonic acid to 5-HETE [3]. 5-HETE can be further metabolized via 5-lipoxygenase to $15(R)$-epi-lipoxin $A_{4}$. Recent studies suggest that lipoxin $A_{4}$ and 15(R)-epi-lipoxin $A_{4}$ are potent protective agents in the stomach, comparable to prostaglandins. As the key event in the pathogenesis of NSAID-induced gastric mucosal injury is the adherence of leukocytes (mainly neutrophils) to the vascular endothelium of the gastric microcirculation, lipoxin $A_{4}$ and 15(R)-epi-lipoxin $A_{4}$ have potent inhibitory effects on neutrophil chemotaxis, adherence and superoxide anion production.

A prospective strategy of NSAID gastropathy prevention is development of inhibitors of COX/5-LOX simultaneously [1, 4]. Licofelone ([2,2-dimethyl-6-(4-chlorophenyl-7-phenyl-2,3-dihydro-1H pyrrolizine-5-yl] acetic acid) is one of the most promising compounds in this group. In experimental studies it was shown that licofelone had significant analgesic and anti-inflammatory effects without any GI side effects [5]. It significantly improved indomethacin-induced gastric ulceration and prevented an NSAID-induced increase in leukotriene levels in the gastric mucosa. The preclinical evaluation has suggested that it has a promising pharmacodynamic effect [6].

Today several different approaches for controlling the NSAID-induced gastric complications have been proposed. According to the American College of Gastroenterology guidelines, proton pump inhibitors (PPIs) are the "gold standard" for the prevention of NSAID gastropathies. Misoprostol, a synthetic prostaglandin $E_{1}$ analogue, is also used in these patients. At the same time budzają adhezję leukocytów do nabłonka naczyniowego w obrębie krążenia trzewnego. Wykazano, że donory $\mathrm{H}_{2} \mathrm{~S}$ ograniczają powstawanie obrzęków i adhezję leukocytów do nabłonka naczyniowego, hamując tym samym syntezę cytokin prozapalnych, zwiększając odporność błony śluzowej układu pokarmowego na uszkodzenia i przyspieszając jej regenerację. W badaniach prowadzonych na szczurach zaobserwowano, że donory $\mathrm{H}_{2} \mathrm{~S}$ blokują adhezję leukocytów do nabłonka naczyniowego indukowaną przez superfuzję drobnych żyłek w krążeniu trzewnym przez prozapalny peptyd formylo-metionyloleucylo-fenyloalaninę. Wykazano, że proces ten ma znaczący udział w patogenezie uszkodzeń żołądkowo-jelitowych wywoływanych przez NLPZ [2]. Zarówno te, jak i inne obserwacje sugerują, że leki przeciwzapalne modyfikowane pod kątem uwalniania $\mathrm{H}_{2} \mathrm{~S}$ będą charakteryzować się większą skutecznością i mniejszą toksycznością.

Lipoksyna $A_{4}\left(L_{X} A_{4}\right)$ i lipoksyna $B_{4}\left(L X B_{4}\right)$ zostały po raz pierwszy zidentyfikowane jako produkty interakcji 5- i 15-lipooksygenazy w aktywowanych leukocytach. W późniejszym okresie lipoksyny wykryto także w komórkach tkanek pacjentów z różnymi schorzeniami zapalnymi o podłożu immunologicznym - np. reumatoidalnym zapaleniem stawów, astmą, zapaleniem płuc itp. Niesteroidowe leki przeciwzapalne odgrywają znaczącą rolę w biosyntezie lipoksyn poprzez zdolność acetylowania kluczowej reszty seryny zarówno w COX-1, jak i COX-2, blokując proces wytwarzania prostanoidów z kwasu arachidonowego. Aktywność COX-1 ulega wówczas całkowitemu zablokowaniu, natomiast COX-2 nadal zachowuje zdolność przekształcania kwasu arachidonowego w 5-HETE [3]. Przy udziale 5-lipooksygenazy 5-HETE może ulegać dalszym przemianom do 15(R)-epi-lipoksyny $A_{4}$. Najnowsze badania wskazują, że lipoksyna $A_{4}$ oraz 15(R)-epi-lipoksyna $A_{4}$ mają silne, porównywalne do prostaglandyn, działanie gastroprotekcyjne. Ponieważ głównym elementem patogenezy indukowanych przez NLPZ uszkodzeń błony śluzowej żołądka jest adhezja leukocytów (głównie neutrofilów) do nabłonka naczyniowego w mikrokrążeniu trzewnym, lipoksyna $A_{4}$ i 15(R)-epi-lipoksyna $\mathrm{A}_{4}$ wykazują silne działanie blokujące chemotaksję neutrofilów, adhezję oraz wytwarzanie anionów nadtlenkowych.

Jedną z prospektywnych strategii zapobiegania gastropatii indukowanej przez NLPZ jest tworzenie podwójnych inhibitorów COX/5-LOX [1, 4]. Jednym z najbardziej obiecujących związków z tej grupy jest likofelon (kwas [2,2-dimetylo-6-(4-chlorofenylo-7-fenylo-2,3-dihydro-1H pirazolino-5-ylo]octowy). Badania eksperymentalne pokazały, że likofelon charakteryzuje się silnym działaniem przeciwbólowym i przeciwzapalnym, a przy tym nie wywołuje żołądkowo-jelitowych działań niepożądanych [5]. Likofelon znacząco łagodził dolegliwości wrzodowe w obrębie żołądka wywoływane przez indometacynę 
we should always remember that chronic use of drugs that markedly suppress gastric acid secretion has been associated with a lot of problems, including bacterial overgrowth [7]. Intake of PPIs has been associated with a significant increase in the incidence of various infections, most notably Clostridium difficile. Recent studies have shown that in patients who use PPIs for a long time, absorption of calcium, iron, magnesium and vita$\min B_{12}$ can be impaired [8].

NSAID use is also associated with significant damage to the more distal regions of the small intestine (i.e. distal to the ligament of Treitz), but the pathogenesis of this injury is less well understood. NSAID enteropathy very often is underexamined or even ignored in most clinical studies, because it is localized in regions that are beyond the reach of typical endoscopic examinations [9].

The approaches taken to prevent NSAID-induced damage in the stomach and duodenum are unlikely to provide a significant benefit in the small intestine. Recent video capsule endoscopy studies have demonstrated the high incidence (55-75\%) of small intestinal damage in healthy volunteers taking NSAIDs plus a PPI over a 2-week period. This high incidence of intestinal damage was observed in a group considered to be at low risk for NSAID-related GI damage, with a short period of treatment.

Recent studies in rodents suggest that PPIs actually exacerbate NSAID-induced enteropathy, rather than provide any beneficial effects [10]. Rats treated with a PPI (omeprazole or lansoprazole) developed substantially more intestinal ulceration and bleeding when concurrently treated with an NSAID (naproxen or celecoxib) than the control group treated with vehicle plus NSAID.

Enteric bacteria (particularly Gram-negative) play an important role in the development of NSAID-induced intestinal ulceration, so exploration of the potential of probiotics and prebiotics is warranted.

In conclusion, it is necessary to continue the studies dedicated to the development of new promising NSAIDs imparting total GI protection, to focus our attention not only on gastroduodenal damage but also on small intestine lesions and to develop surrogate markers of intestinal damage.

Authors declare no conflict of interests. oraz zapobiegat indukowanemu przez NLPZ wzrostowi stężenia leukotrienów w błonie śluzowej żołądka. Wyniki oceny przedklinicznej związku sugerują ponadto, że posiada obiecujący profil farmakodynamiczny [6].

Dotąd zaproponowano kilka różnych metod ograniczania powikłań żołądkowych indukowanych przez NLPZ. Zgodnie z wytycznymi Amerykańskiego Kolegium Gastroenterologii „złotym standardem” w profilaktyce gastropatii indukowanych przez NLPZ są inhibitory pompy protonowej. U pacjentów stosuje się także mizoprostol - syntetyczny analog prostaglandyny $E_{1}$. Należy jednak pamiętać, że przewlekłe stosowanie leków, które w znacznym stopniu blokują wydzielanie kwasu żołądkowego, wiąże się z licznymi problemami, np. przerostem flory bakteryjnej [7]. Leczenie oparte na inhibitorach pompy protonowej może istotnie zwiększać częstość występowania zakażeń, zwłaszcza infekcji bakterią Clostridium difficile. W najnowszych badaniach wykazano, że u pacjentów długotrwale stosujących inhibitory pompy protonowej może dochodzić do upośledzenia wchłaniania wapnia, żelaza, magnezu oraz witaminy $\mathrm{B}_{12}[8]$.

Stosowanie NLPZ jest także związane ze znaczącym uszkodzeniem odcinków jelita cienkiego położonych dystalnie w stosunku do więzadła Treitza, jednak patogeneza tego rodzaju uszkodzeń nie została wystarczająco wyjaśniona. Enteropatia indukowana przez leki z grupy NLPZ jest stosunkowo często nierozpoznawana, a wręcz ignorowana w większości badań klinicznych, ponieważ dotyczy obszaru, który znajduje się poza zasięgiem typowych badań endoskopowych [9].

Należy przyjąć, że metody zapobiegania uszkodzeniom indukowanym przez NLPZ w żołądku i dwunastnicy nie przynoszą istotnych korzyści w jelicie cienkim. Niedawne badania przeprowadzone metodą endoskopii kapsułkowej (VCE) potwierdzity dużą częstość występowania (55-75\%) uszkodzeń jelita cienkiego u zdrowych ochotników stosujących NLPZ łącznie z lekami z grupy inhibitorów pompy protonowej przez dwa tygodnie. Warto zaznaczyć, że powyższych obserwacji dokonano w grupie niskiego ryzyka występowania uszkodzeń żołądkowo-jelitowych indukowanych NLPZ oraz po krótkim czasie leczenia.

Najnowsze badania na gryzoniach pokazują, że inhibitory pompy protonowej nie przynoszą korzyści terapeutycznych i mogą wręcz nasilać enteropatię wywoływaną przez NLPZ [10]. U szczurów, którym podawano inhibitor pompy protonowej (omeprazol lub lanzoprazol), nasilenie wrzodów jelita i krwawień było większe w grupie zwierząt jednocześnie leczonych NLPZ (naproksenem lub celekoksybem) niż w grupie kontrolnej otrzymującej nośnik i NLPZ.

Ponieważ w powstawaniu wrzodów jelitowych indukowanych przez NLPZ ważną rolę odgrywają bakterie jelitowe (zwłaszcza Gram-ujemne), uzasadnione wydaje się również zbadanie potencjału, jaki mają pro- i prebiotyki. 


\section{References}

\section{Piśmiennictwo}

1. Sinha M, Gautam L, Shukla PK, et al. Current perspectives in NSAID-induced gastropathy. Mediators Inflamm 2013; 2013: 258209.

2. Oh GS, Pae HO, Lee BS, et al. Hydrogen sulfide inhibits nitric oxide production and nuclear factor-kappa B via heme oxygenase-1 expression in RAW264.7 macrophages stimulated with lipopolysaccharide. Free Rad Biol Med 2006; 41: 106-119.

3. Serhan CN. Lipoxins and aspirin-triggered 15-epi-lipoxins are the first lipid mediators of endogenous anti-inflammation and resolution. Prostaglandins Leukot Essent Fatty Acids 2005; 73: 141-162.

4. Martel-Pelletier J, Lajeunesse D, Pelletier J. Therapeutic role of dual inhibitors of 5-LOX and COX, selective and non-selective non-steroidal anti-inflammatory drugs. Ann Rheum Dis 2003; 62: 501-509.

5. Ulbrich H, Soehnlein O, Xie X, et al. Licofelone, a novel 5-LOX/ COX-inhibitor, attenuates leukocyte rolling and adhesion on endothelium under flow. Biochem Pharmacol 2005; 70: 30-36.

W podsumowaniu należy podkreślić, że niezbędne jest kontynuowanie badań zmierzających do opracowania nowych NLPZ, które zapewniałyby pełną ochronę układu pokarmowego. Uwagę należy koncentrować nie tylko na uszkodzeniach żołądka i dwunastnicy, lecz także na zmianach występujących w jelicie cienkim oraz trzeba dążyć do stworzenia zastępczych markerów dla uszkodzeń jelitowych.

Autorzy deklarują brak konfliktu interesów.

6. Cicero AF, Laghi L. Activity and potential role of licofelone in the management of osteoarthritis. Clin Interv Aging 2007; 2: 73-79.

7. Lombardo L, Foti M, Ruggia $O$ et al. Increased incidence of small intestinal bacterial overgrowth during proton pump inhibitor therapy. Clin Gastroenterol Hepatol 2010; 8: 504-508.

8. Ito T, Jensen RT. Association of long-term proton pump inhibitor therapy with bone fractures and effects on absorption of calcium, vitamin B12, iron, and magnesium. Curr Gastroenterol 2010; 12: 448-457.

9. Wallace JL. NSAID gastropathy and enteropathy: distinct pathogenesis likely necessitates distinct prevention strategies. Br J Pharmacol 2012; 165: 67-74.

10. Wallace JL, Denou E, Vong L, et al. Proton pump inhibitors and low-dose aspirin markedly exacerbate NSAID-induced small intestinal injury: link to dysbiosis? Gastroenterology 2011; 140: 68-87. 